\title{
<論 文 >
}

\section{二官能性環状カーボナートとジアミンとの開環重付加による ポリヒドロキシウレタンの合成とそのフィルム物性}

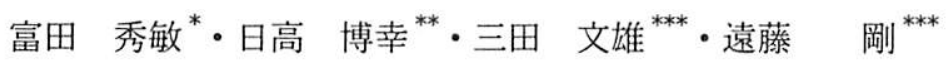

\section{要旨}

炭酸ガスとジエポキシドから, 臭化リチゥムを触媒として用い, 各種の二官能性環状カーボナート 類を合成し，これらに各種のジアミンを重付加させることにより，相当するポリヒト゚ロキシウレタン を得た。得られたポリヒドロキシゥレタンのフィルム物性を測定したところ, 吸湿の程度により抗 張力および伸び率に大きな変化が観察され, さらに, 従来のポリウレタンには無い高い吸水性と熱安 定性が認められた。

\section{1. 緒 言}

1937 年に I. G. Farbenindustrie 社の Bayer ら ${ }^{1,2)} に$ よって開発されて以来, ポリウレタンは合成樹脂の中で 非常に幅広い用途をもつ材料のひとつとなっている。ポ リウレタンは耐候性や耐薬品性などの優れた特性に加え て, 加工性にも富むことから, 様々な形状の製品が様々 な製法で作られ, 今日, 輸送・家具・土木建材・生活用 品・産業機器・海洋・医療・スポーツ等, 幅広い産業分 野に使用されており, 国内需要は年間約 60 万トンにも のぼる3.4)。ポリウレタンは二官能性イソシアナートと アルコールとの重付加により合成されているが, 原料イ ソシアナートの高反応性のため, 尿素結合, アロファネー 卜結合、ピュレット結合が副生し，分岐を有する複雑な 構造を持ち, さらにこれらの異種構造は耐熱性, 柔乾性 等の物性低下を招く3)。そこで, 本研究では二官能性環 状カーボナートとジアミンを原料とする新規製法により, 副反応を伴うこと無く, 側鎖に水酸基を有する新規なポ リウレタンを合成し，その物理的特性を評価した。これ らポリヒドロキシウレタンには従来には無かった高い親
水性といった新規機能の発現が期待される。

\section{2. 実 験}

\section{1 測定装置}

NMR 測定はテトラメチルシランを内部標準物質とし, 重クロロホルム中で，日本電子製の LA-300 (300 MHz) を用いて行った。IR 測定は日本分光製の FT/IR-5300 を使用した。 GPC 測定は $10 \mathrm{mmol} / \mathrm{L}$ の臭化リチウムを

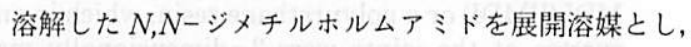
東ソー製の HLC-8020を用いて行った。引張試験は島 津製作所製の AGS- $5 \mathrm{kNG}$ を使用した。TG-DTA 測定 は理学電機製の THERMOFLEX TG8110を使用した。

\section{2 二官能性環状カーボナートの合成}

我々は臭化リチゥムを触媒として用いることにより， 炭酸ガスとエポキシドから常圧下で定量的に環状カーボ ナートが得られることを報告している。（参照 Scheme 1) ${ }^{5)}$ この応を用いて, Scheme 2 に示す各種の二官能 性環状カーボナート 1 を合成した。1a 及び $1 \mathrm{~d}$ はトルエ ン溶液からの再結晶により, 1b はカラムクロマトグラ
*(財) 化学技術戦略推進機構

（東京工業大学資源化学研究所内）

神奈川県横浜市緑区長津田町 4259 个 226-8503

**大日本インキ化学工業株式会社. 大阪府高石市高砂 1-3 个 592-0001

**** 東京工業大学资源化学研究所

神奈川県横浜市緑区長津田町 4259 † 226-8503

(原稿受付日: 平成 12 年 2 月 4 日)

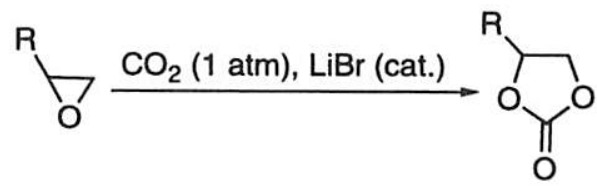

Scheme 1 


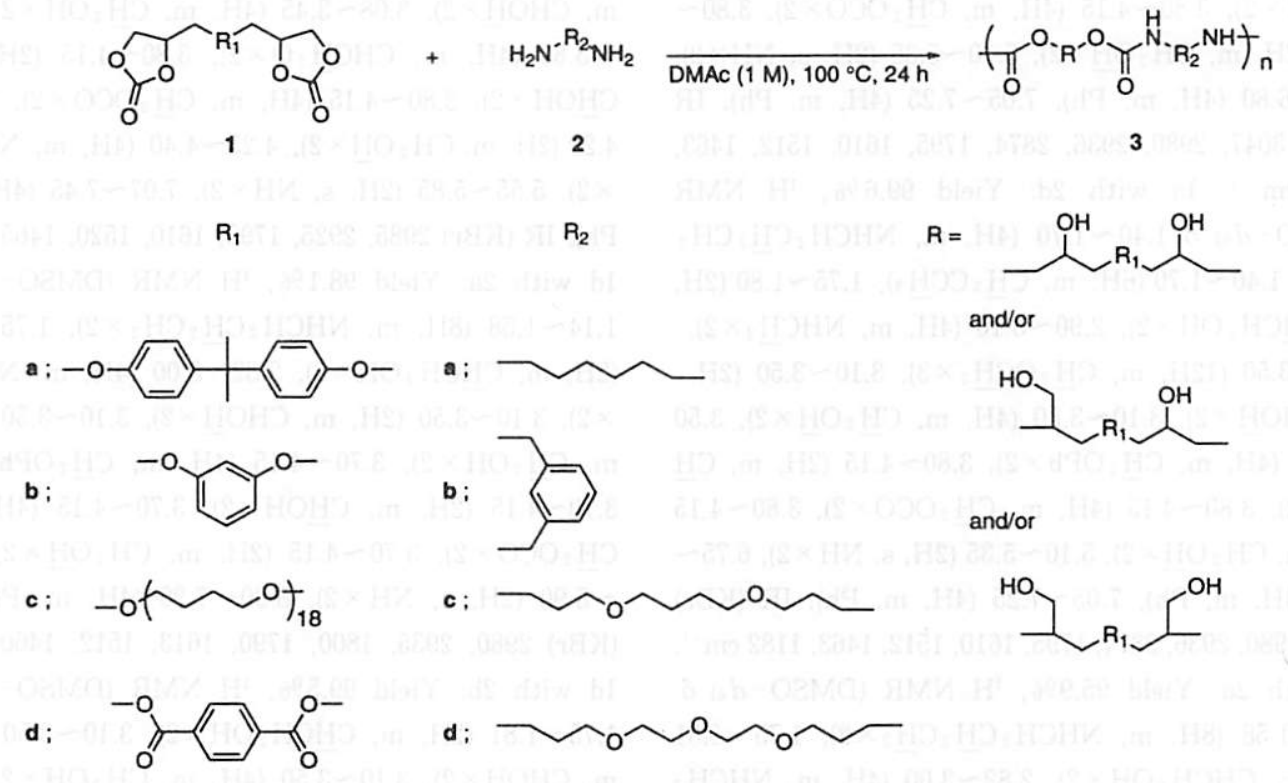

Scheme 2

フィー（展開溶媒：酢酸エチル）により，1cは水で再 沈殿することにより精製した。1a: Yield $74.3 \%,{ }^{1} \mathrm{H}$ NMR (DMSO- $\left.d_{6}\right) \delta 1.58\left(6 \mathrm{H}, \mathrm{s}, \mathrm{CH}_{3} \times 2\right), 4.14 \sim 4.26$ $\left(4 \mathrm{H}, \mathrm{m}, \mathrm{PhOCH}^{2} \times 2\right), 4.36 \sim 4.39\left(2 \mathrm{H}, \mathrm{m}, \mathrm{OCH}_{2} \mathrm{CH}\right)$, $4.60 \sim 4.64\left(2 \mathrm{H}, \mathrm{m}, \mathrm{OCH}_{2} \mathrm{CH}\right), 5.10 \sim 5.20(2 \mathrm{H}, \mathrm{m}$, $\mathrm{CH} \times 2), 6.84(4 \mathrm{H}, \mathrm{d}, J=8.4 \mathrm{~Hz}, \mathrm{Ph}), 7.11 \sim 7.13(4 \mathrm{H}$, d, $J=8.4 \mathrm{~Hz}, \mathrm{Ph}$ ), IR (KBr) 3046, 2982, 2932, 2876, $1790,1607,1510,1460,1179 \mathrm{~cm}^{-1}$. M.p. $155-156^{\circ} \mathrm{C}$. Anal. Calcd for $\mathrm{C}_{23} \mathrm{H}_{24} \mathrm{O}_{8}$ : C, 64.48; H, 5.65;. Found: C, 64.50; H, 5.49. 1b: Yield 83.6\%, ' $\mathrm{H}$ NMR (DMSO$\left.d_{6}\right) \delta 4.18 \sim 4.40\left(4 \mathrm{H}, \mathrm{m}, \mathrm{PhOCH}_{2} \mathrm{CH} \times 2\right), 4.36 \sim 4.40$ $\left(2 \mathrm{H}, \mathrm{m}, \underline{\mathrm{CH}}_{2} \mathrm{OC}=\mathrm{O}\right), 4.61 \sim 4.65\left(2 \mathrm{H}, \mathrm{m}, \mathrm{CH}_{2} \mathrm{OC}=\right.$ O), $5.12 \sim 5.17(2 \mathrm{H}, \mathrm{m}, \mathrm{CH} \times 2), 6.56 \sim 6.61(3 \mathrm{H}, \mathrm{m}$, $\mathrm{Ph}), 7.20 \sim 7.25$ (1H, m, Ph), IR (NaCl) 2975, 2928, 1753, 1578, 1499, 1470, $1196 \mathrm{~cm}^{-1}$. Anal. Calcd for $\mathrm{C}_{14} \mathrm{H}_{14} \mathrm{O}_{8}$ : C, 54.20; H, 4.55;. Found: C, 54.82; H, 5.01. 1c: Yield $94.2 \%,{ }^{1} \mathrm{H}$ NMR $\left(\mathrm{DMSO}-d_{6}\right) \delta 1.51$ $\left(72 \mathrm{H}, \mathrm{s}, \mathrm{OCH}_{2} \mathrm{CH}_{2} \mathrm{CH}_{2} \mathrm{CH}_{2} \mathrm{O} \times 18\right), 3.33(72 \mathrm{H}, \mathrm{s}$, $\left.\mathrm{OCH}_{2} \mathrm{CH}_{2} \mathrm{CH}_{2} \underline{\mathrm{CH}}_{2} \mathrm{O} \times 18\right), 3.52 \sim 3.64\left(4 \mathrm{H}, \mathrm{m}, \mathrm{CH}_{2}\right.$ $\left.\mathrm{OCH}_{2} \mathrm{CH} \times 2\right), 4.22 \sim 4.26(2 \mathrm{H}, \mathrm{m}, \mathrm{CH} \times 2), 4.50 \sim 4.53$ $\left(2 \mathrm{H}, \mathrm{m}, \mathrm{CH}_{2} \mathrm{OC}=\mathrm{O}\right), 4.80 \sim 4.90\left(2 \mathrm{H}, \mathrm{m}, \mathrm{CH}_{2} \mathrm{OC}=\right.$ O), IR ( $\mathrm{NaCl}) 2942,2857,1790,1113 \mathrm{~cm}^{-1}$. Anal. Calcd for $\mathrm{C}_{80} \mathrm{H}_{154} \mathrm{O}_{25}$ : C, 63.38; H, 10.24;. Found: C, 64.20; H, 11.12. 1d: Yield 67.2\%, ' $\mathrm{H}$ NMR (DMSO$\left.d_{6}\right) \delta 4.45 \sim 4.60\left(4 \mathrm{H}, \mathrm{m}, \mathrm{CH}_{2} \mathrm{OCOPh} \times 2\right), 4.60 \sim 4.70$ $\left(4 \mathrm{H}, \mathrm{m}, \mathrm{CH}_{2} \mathrm{OCOO} \times 2\right), 5.20 \sim 5.30\left(2 \mathrm{H}, \mathrm{m}, \mathrm{CH}_{2} \mathrm{CH}\right.$ $\times 2), 8.10(4 \mathrm{H}, \mathrm{s}, \mathrm{Ph}), \mathrm{IR}(\mathrm{KBr}) 2991,2930,2872$,
$1790,1770,1610,1515,1467 \mathrm{~cm}^{-1}$. M.p. $150-151^{\circ} \mathrm{C}$. Anal. Calcd for $\mathrm{C}_{16} \mathrm{H}_{14} \mathrm{O}_{10}$ : C, 52.47; H, 3.85;. Found: C, 52.30; H, 3.80 .

\section{3 ポリヒドロキシウレタンの合成}

Scheme 2 に示すように, 二官能性環状カーボナート $1(10.0 \mathrm{mmol})$ とジアミン $2(10.0 \mathrm{mmol})$ とをジメチルア セトアミド (DMAc) 中で $100^{\circ} \mathrm{C}, 24$ 時間反応させる ことにより, 目的物であるポリヒドロキシウレタンを得 た。ポリマーは水またはエーテルに重合混合液を投入し, 沈殿させることにより単離精製した。1a with 2a: Yield $99.1 \%,{ }^{1} \mathrm{H}$ NMR $\left(\mathrm{DMSO}-d_{6}\right) \delta 1.00 \sim 1.65(8 \mathrm{H}, \mathrm{m}$, $\left.\mathrm{NHCH}_{2} \underline{\mathrm{CH}}_{2} \underline{\mathrm{CH}}_{2} \times 2\right), 1.00 \sim 1.65\left(6 \mathrm{H}, \mathrm{m}, \underline{\mathrm{CH}}_{3} \mathrm{CCH}_{3}\right)$, $1.00 \sim 1.65\left(2 \mathrm{H}, \mathrm{m}, \mathrm{CHCH}_{2} \mathrm{OH} \times 2\right), 2.80 \sim 3.00(4 \mathrm{H}$, $\left.\mathrm{m}, \mathrm{NHCH}_{2} \times 2\right), 3.10 \sim 3.50(2 \mathrm{H}, \mathrm{m}, \mathrm{CHO} \underline{\mathrm{H}} \times 2), 3.10$ $\sim 3.50\left(4 \mathrm{H}, \mathrm{m}, \mathrm{CH}_{2} \mathrm{OH} \times 2\right), 3.50 \sim 3.65\left(4 \mathrm{H}, \mathrm{m}, \mathrm{CH}_{2}\right.$ $\mathrm{OPh} \times 2), \quad 3.80 \sim 4.15(2 \mathrm{H}, \mathrm{m}, \mathrm{C} \underline{\mathrm{HOH}} \times 2), \quad 3.80 \sim 4.15$ $\left(4 \mathrm{H}, \mathrm{m}, \mathrm{CH}_{2} \mathrm{OCO} \times 2\right), 3.80 \sim 4.15\left(2 \mathrm{H}, \mathrm{m}, \mathrm{CH}_{2} \mathrm{OH} \times\right.$ 2), $5.65 \sim 5.90(2 \mathrm{H}, \mathrm{s}, \mathrm{NH} \times 2), 6.75 \sim 6.80(4 \mathrm{H}, \mathrm{m}, \mathrm{Ph})$, $7.05 \sim 7.25$ (4H, m, Ph), IR (KBr) 3043, 2981, 2937, $2870,1793,1610,1510,1465 \mathrm{~cm}^{-1}$. 1a with 2c: Yield $99.0 \%,{ }^{1} \mathrm{H}$ NMR (DMSO $\left.-d_{6}\right) \delta 1.40 \sim 1.70(4 \mathrm{H}, \mathrm{m}$, $\left.\mathrm{NHCH}_{2} \underline{\mathrm{CH}}_{2} \mathrm{CH}_{2} \mathrm{O} \times 2\right), 1.40 \sim 1.70\left(4 \mathrm{H}, \mathrm{m}, \mathrm{OCH}_{2} \mathrm{CH}_{2}\right.$ $\left.\mathrm{CH}_{2} \mathrm{CH}_{2} \mathrm{O}\right), 1.40 \sim 1.70\left(6 \mathrm{H}, \mathrm{m}, \mathrm{CH}_{2} \mathrm{CCH}_{3}\right), 1.75 \sim$ $1.80\left(2 \mathrm{H}, \mathrm{m}, \mathrm{CHCH}_{2} \mathrm{OH} \times 2\right), 2.90 \sim 3.10\left(4 \mathrm{H}, \mathrm{m}, \mathrm{NHCH}_{2}\right.$ $\times 2), 3.10 \sim 3.50\left(8 \mathrm{H}, \mathrm{m}, \mathrm{CH}_{2} \mathrm{OCH}_{2} \times 2\right), 3.10 \sim 3.50$ $(2 \mathrm{H}, \mathrm{m}, \mathrm{CHOH} \times 2), 3.10 \sim 3.50\left(4 \mathrm{H}, \mathrm{m}, \mathrm{CH}_{2} \mathrm{OH} \times 2\right)$, $3.50 \sim 3.65\left(4 \mathrm{H}, \mathrm{m}, \mathrm{CH}_{2} \mathrm{OPh} \times 2\right), 3.80 \sim 4.15(2 \mathrm{H}, \mathrm{m}$, 
$\mathrm{C} \underline{\mathrm{HOH}} \times 2), \quad 3.80 \sim 4.15\left(4 \mathrm{H}, \mathrm{m}, \mathrm{CH}_{2} \mathrm{OCO} \times 2\right), 3.80 \sim$ $4.15\left(2 \mathrm{H}, \mathrm{m}, \mathrm{CH}_{2} \mathrm{OH} \times 2\right), 5.10 \sim 5.35(2 \mathrm{H}, \mathrm{s}, \mathrm{NH} \times 2)$, $6.75 \sim 6.80(4 \mathrm{H}, \mathrm{m}, \mathrm{Ph}), 7.05 \sim 7.25(4 \mathrm{H}, \mathrm{m}, \mathrm{Ph}), \mathrm{IR}$ (KBr) 3047, 2980, 2936, 2874, 1795, 1610, 1512, 1463, $1182 \mathrm{~cm}^{-1}$. 1a with 2d: Yield $99.6 \%$, 'H NMR $\left(\mathrm{DMSO}-d_{6}\right) \delta 1.40 \sim 1.70\left(4 \mathrm{H}, \mathrm{m}, \mathrm{NHCH}_{2} \mathrm{CH}_{2} \mathrm{CH}_{2}\right.$ $\mathrm{O} \times 2), 1.40 \sim 1.70\left(6 \mathrm{H}, \mathrm{m}, \mathrm{CH}_{3} \mathrm{CCH}_{3}\right), 1.75 \sim 1.80(2 \mathrm{H}$, $\left.\mathrm{m}, \mathrm{CHCH}_{2} \mathrm{OH} \times 2\right), 2.90 \sim 3.10\left(4 \mathrm{H}, \mathrm{m}, \mathrm{NHCH}_{2} \times 2\right)$, $3.10 \sim 3.50\left(12 \mathrm{H}, \mathrm{m}, \mathrm{CH}_{2} \mathrm{OCH}_{2} \times 3\right), 3.10 \sim 3.50(2 \mathrm{H}$, $\mathrm{m}, \mathrm{CHO} \underline{\mathrm{H}} \times 2), 3.10 \sim 3.50\left(4 \mathrm{H}, \mathrm{m}, \mathrm{CH}_{2} \mathrm{O} \underline{\mathrm{H}} \times 2\right), 3.50$ $\sim 3.65\left(4 \mathrm{H}, \mathrm{m}, \mathrm{CH}_{2} \mathrm{OPh} \times 2\right), 3.80 \sim 4.15(2 \mathrm{H}, \mathrm{m}, \mathrm{CH}$ $\mathrm{OH} \times 2), 3.80 \sim 4.15\left(4 \mathrm{H}, \mathrm{m}, \mathrm{CH}_{2} \mathrm{OCO} \times 2\right), 3.80 \sim 4.15$ $\left(2 \mathrm{H}, \mathrm{m}, \mathrm{CH}_{2} \mathrm{OH} \times 2\right), 5.10 \sim 5.35(2 \mathrm{H}, \mathrm{s}, \mathrm{NH} \times 2), 6.75 \sim$ $6.80(4 \mathrm{H}, \mathrm{m}, \mathrm{Ph}), 7.05 \sim 7.25(4 \mathrm{H}, \mathrm{m}, \mathrm{Ph}), \mathrm{IR}(\mathrm{KBr})$ $3047,2980,2936,2874,1795,1610,1512,1463,1182 \mathrm{~cm}^{-1}$. $1 \mathrm{~b}$ with $2 \mathrm{a}$ : Yield $95.9 \%$, 'H NMR (DMSO $\left.-d_{6}\right) \delta$ $1.14 \sim 1.58\left(8 \mathrm{H}, \mathrm{m}, \mathrm{NHCH}_{2} \mathrm{CH}_{2} \mathrm{CH}_{2} \times 2\right), 1.75 \sim 1.81$ $\left(2 \mathrm{H}, \mathrm{m}, \mathrm{CHCH}_{2} \mathrm{OH} \times 2\right), 2.82 \sim 3.00\left(4 \mathrm{H}, \mathrm{m}, \mathrm{NHCH}_{2}\right.$ $\times 2), 3.10 \sim 3.50(2 \mathrm{H}, \mathrm{m}, \mathrm{CHOH} \times 2), 3.10 \sim 3.50(4 \mathrm{H}$, $\left.\mathrm{m}, \quad \mathrm{CH}_{2} \mathrm{OH} \times 2\right), \quad 3.50 \sim 3.70\left(4 \mathrm{H}, \mathrm{m}, \mathrm{CH}_{2} \mathrm{OPh} \times 2\right)$, $3.80 \sim 4.15(2 \mathrm{H}, \mathrm{m}, \mathrm{C}$ $\left.\mathrm{CH}_{2} \mathrm{OCO} \times 2\right), \quad 3.80 \sim 4.15\left(2 \mathrm{H}, \mathrm{m}, \mathrm{CH}_{2} \mathrm{O} \underline{\mathrm{H}} \times 2\right), 5.60$ $\sim 5.90(2 \mathrm{H}, \mathrm{s}, \mathrm{NH} \times 2), 7.25 \sim 7.40(4 \mathrm{H}, \mathrm{m}, \mathrm{Ph}), \mathrm{IR}$ (KBr) 2980, 2935, 1790,1610,1510,1460 $\mathrm{cm}^{-1} .1 \mathrm{~b}$ with 2b: Yield 98.9\%, ' $\mathrm{H}$ NMR (DMSO- $d_{6}$ ) $\delta 1.75$ $\sim 1.81\left(2 \mathrm{H}, \mathrm{m}, \mathrm{CHCH}_{2} \mathrm{OH} \times 2\right), 2.82 \sim 3.00(4 \mathrm{H}, \mathrm{m}$, $\left.\mathrm{NHCH}_{2} \times 2\right), \quad 3.10 \sim 3.50(2 \mathrm{H}, \mathrm{m}, \mathrm{CHOH} \times 2), 3.10 \sim$ $3.50\left(4 \mathrm{H}, \mathrm{m}, \mathrm{CH}_{2} \mathrm{OH} \times 2\right), 3.50 \sim 3.70\left(4 \mathrm{H}, \mathrm{m}, \mathrm{CH}_{2}\right.$ $\mathrm{OPh} \times 2), 3.80 \sim 4.15(2 \mathrm{H}, \mathrm{m}, \mathrm{CHOH} \times 2), 3.80 \sim 4.15$ $\left(4 \mathrm{H}, \mathrm{m}, \mathrm{CH}_{2} \mathrm{OCO} \times 2\right), 3.80 \sim 4.15\left(2 \mathrm{H}, \mathrm{m}, \mathrm{CH}_{2} \mathrm{OH} \times\right.$ 2), $4.25 \sim 4.40\left(4 \mathrm{H}, \mathrm{m}, \mathrm{CH}_{2} \mathrm{Ph} \times 2\right), 4.75 \sim 4.85(2 \mathrm{H}, \mathrm{s}$, $\mathrm{NH} \times 2), 7.08 \sim 7.40(8 \mathrm{H}, \mathrm{m}, \mathrm{Ph}), \mathrm{IR}(\mathrm{KBr}) 2985,2930$, $1793,1612,1517,1461 \mathrm{~cm}^{-1}$. 1c with 2a: Yield $98.5 \%$, ${ }^{1} \mathrm{H}$ NMR $\left(\mathrm{DMSO}-d_{6}\right) \delta 1.14 \sim 1.58\left(8 \mathrm{H}, \mathrm{m}, \mathrm{NHCH}_{2}\right.$ $\left.\mathrm{CH}_{2} \mathrm{CH}_{2} \times 2\right), 1.14 \sim 1.58\left(72 \mathrm{H}, \mathrm{s}, \mathrm{OCH}_{2} \mathrm{CH}_{2} \mathrm{CH}_{2} \mathrm{CH}_{2}\right.$ $\mathrm{O} \times 18), 1.70 \sim 1.77\left(2 \mathrm{H}, \mathrm{m}, \mathrm{CHCH}_{2} \mathrm{OH} \times 2\right), 2.82 \sim 3.00$ $\left(4 \mathrm{H}, \mathrm{m}, \mathrm{NHCH}_{2} \times 2\right), 3.08 \sim 3.45\left(72 \mathrm{H}, \mathrm{s}, \mathrm{OCH}_{2} \mathrm{CH}_{2}\right.$ $\left.\mathrm{CH}_{2} \mathrm{CH}_{2} \mathrm{O} \times 18\right), 3.08 \sim 3.45(2 \mathrm{H}, \mathrm{m}, \mathrm{CHOH} \times 2), 3.08$ $\sim 3.45\left(4 \mathrm{H}, \mathrm{m}, \mathrm{CH}_{2} \mathrm{OH} \times 2\right), 3.45 \sim 3.65(4 \mathrm{H}, \mathrm{m}, \mathrm{CH}$ $\left.\mathrm{CH}_{2} \mathrm{O} \times 2\right), 3.80 \sim 4.15(2 \mathrm{H}, \mathrm{m}, \mathrm{CHOH} \times 2), 3.80 \sim 4.15$ $\left(4 \mathrm{H}, \mathrm{m}, \mathrm{CH}_{2} \mathrm{OCO} \times 2\right), 3.80 \sim 4.20\left(2 \mathrm{H}, \mathrm{m}, \mathrm{CH}_{2} \mathrm{O} \underline{\mathrm{H}} \times\right.$ 2), $5.55 \sim 5.85(2 \mathrm{H}, \mathrm{s}, \mathrm{NH} \times 2)$, IR $(\mathrm{KBr}) 2982,2932$, $1790,1460 \mathrm{~cm}^{-1}$. 1c with $2 \mathrm{~b}$ : Yield $99.1 \%$, ${ }^{1} \mathrm{H}$ NMR $\left(\mathrm{DMSO}-d_{6}\right) \delta 1.40 \sim 1.60\left(72 \mathrm{H}, \mathrm{s}, \mathrm{OCH}_{2} \mathrm{CH}_{2} \mathrm{CH}_{2} \mathrm{CH}_{2}\right.$ $\mathrm{O} \times 18), 1.70 \sim 1.77\left(2 \mathrm{H}, \mathrm{m}, \mathrm{CHCH}_{2} \mathrm{OH} \times 2\right), 3.08 \sim 3.45$ $\left(72 \mathrm{H}, \mathrm{s}, \mathrm{OCH}_{2} \mathrm{CH}_{2} \mathrm{CH}_{2} \mathrm{CH}_{2} \mathrm{O} \times 18\right), 3.08 \sim 3.45(2 \mathrm{H}$, m, $\mathrm{CHOH} \times 2), 3.08 \sim 3.45\left(4 \mathrm{H}, \mathrm{m}, \mathrm{CH}_{2} \mathrm{OH} \times 2\right), 3.45$ $\sim 3.65\left(4 \mathrm{H}, \mathrm{m}, \mathrm{CHCH}_{2} \mathrm{O} \times 2\right), 3.80 \sim 4.15(2 \mathrm{H}, \mathrm{m}$, $\mathrm{C} \underline{\mathrm{HOH}} \times 2), \quad 3.80 \sim 4.15\left(4 \mathrm{H}, \mathrm{m}, \mathrm{CH}_{2} \mathrm{OCO} \times 2\right), 3.80 \sim$ $4.20\left(2 \mathrm{H}, \mathrm{m}, \mathrm{CH}_{2} \mathrm{OH} \times 2\right), 4.25 \sim 4.40\left(4 \mathrm{H}, \mathrm{m}, \mathrm{NHCH}_{2}\right.$ $\times 2), 5.55 \sim 5.85(2 \mathrm{H}, \mathrm{s}, \mathrm{NH} \times 2), 7.07 \sim 7.45(4 \mathrm{H}, \mathrm{m}$, $\mathrm{Ph})$, IR (KBr) 2985, 2925, 1795, 1610, 1520, $1465 \mathrm{~cm}^{-1}$. 1d with 2a: Yield 98.1\%, ${ }^{1} \mathrm{H}$ NMR (DMSO- $d_{6}$ ) $\delta$ $1.14 \sim 1.58\left(8 \mathrm{H}, \mathrm{m}, \mathrm{NHCH}_{2} \underline{\mathrm{CH}}_{2} \mathrm{CH}_{2} \times 2\right), 1.75 \sim 1.81$ $\left(2 \mathrm{H}, \mathrm{m}, \mathrm{CHCH}_{2} \mathrm{OH} \times 2\right), 2.82 \sim 3.00\left(4 \mathrm{H}, \mathrm{m}, \mathrm{NHCH}_{2}\right.$ $\times 2), 3.10 \sim 3.50(2 \mathrm{H}, \mathrm{m}, \mathrm{CHOH} \times 2), 3.10 \sim 3.50(4 \mathrm{H}$, $\left.\mathrm{m}, \quad \underline{\mathrm{C}}_{2} \mathrm{OH} \times 2\right), \quad 3.70 \sim 4.15\left(4 \mathrm{H}, \mathrm{m}, \mathrm{CH}_{2} \mathrm{OPh} \times 2\right)$, $3.70 \sim 4.15(2 \mathrm{H}, \mathrm{m}, \mathrm{CHOH} \times 2), 3.70 \sim 4.15(4 \mathrm{H}, \mathrm{m}$, $\left.\mathrm{CH}_{2} \mathrm{OCO} \times 2\right), \quad 3.70 \sim 4.15\left(2 \mathrm{H}, \mathrm{m}, \mathrm{CH}_{2} \mathrm{OH} \times 2\right), 5.60$ $\sim 5.90(2 \mathrm{H}, \mathrm{s}, \mathrm{NH} \times 2), 8.00 \sim 7.20(4 \mathrm{H}, \mathrm{m}, \mathrm{Ph}), \mathrm{IR}$ (KBr) 2980, 2935, 1800,1790,1613,1512, $1460 \mathrm{~cm}^{-1}$. 1d with $2 \mathrm{~b}$ : Yield $99.5 \%,{ }^{1} \mathrm{H}$ NMR (DMSO- $\left.d_{6}\right) \delta$ $1.75 \sim 1.81\left(2 \mathrm{H}, \mathrm{m}, \mathrm{CHCH}_{2} \mathrm{OH} \times 2\right), 3.10 \sim 3.50(2 \mathrm{H}$, $\mathrm{m}, \mathrm{CHO} \underline{\mathrm{H}} \times 2), \quad 3.10 \sim 3.50\left(4 \mathrm{H}, \mathrm{m}, \mathrm{CH}_{2} \mathrm{OH} \times 2\right), 3.70$ $\sim 4.35\left(4 \mathrm{H}, \mathrm{m}, \mathrm{NHCH}_{2} \times 2\right), 3.70 \sim 4.35\left(4 \mathrm{H}, \mathrm{m}, \underline{\mathrm{CH}}_{2}\right.$ $\mathrm{OPh} \times 2), 3.70 \sim 4.35(2 \mathrm{H}, \mathrm{m}, \mathrm{C} \underline{\mathrm{HOH}} \times 2), 3.70 \sim 4.35$ $\left(4 \mathrm{H}, \mathrm{m}, \mathrm{CH}_{2} \mathrm{OCO} \times 2\right), 3.70 \sim 4.35\left(2 \mathrm{H}, \mathrm{m}, \mathrm{CH}_{2} \mathrm{OH} \times\right.$ 2), $5.60 \sim 5.90(2 \mathrm{H}, \mathrm{s}, \mathrm{NH} \times 2), 7.07 \sim 7.45(4 \mathrm{H}, \mathrm{m}, \mathrm{Ph})$, $8.00 \sim 7.20(4 \mathrm{H}, \mathrm{m}, \mathrm{Ph}), \mathrm{IR}(\mathrm{KBr}) 2998,2948,1800$, $1795,1615,1516,1460 \mathrm{~cm}^{-1}$.

\section{4 フィルムの作成}

ポリヒドロキシウレタンの DMF 溶液をポリプロピレン により表面被覆された離型紙上に, ナイフオーバーロール コーターを使用して㳂布した。その後, Werner Mathis $\mathrm{AG}$ 乾燥機 (LTF タイプ) を使用して, $70^{\circ} \mathrm{C} \times 2$ 分, さらに $150^{\circ} \mathrm{C} \times 3$ 分乾燥させた。常態放置した試料は試 料をシリカゲルおよび五酸化リンの存在下, デシケーター 中でさらに, 2 日間隇圧乾燥し，5 日間大気中に放置す ることにより調製した。乾燥試料は試料をシリカゲルお よび五酸化リンの存在下, デシケーター中で 1 週間隇圧 乾燥することにより調製した。これらの操作を経て, 膜 厚が約 $50 \mu \mathrm{m}$ の均質なフィルムを得た。

\section{5 抗張力および伸び率の測定}

試験片は膜厚約 $50 \mu \mathrm{m}$, 幅 $5 \mathrm{~mm}$, 長さ $70 \mathrm{~mm}$ となる ように作成した。試験は引張試験機を用いて,つかみ間 隔 $20 \mathrm{~mm}$, 引張速度 $300 \mathrm{~mm} / \mathrm{min}$ で行った。このとき

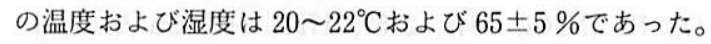
測定は各々 5 回行い，平均値を算出した。

\subsection{TG-DTA の測定}

試料量は $10 \sim 40 \mathrm{mg}$ とし, 窒素等囲気下で室温 500 ${ }^{\circ} \mathrm{C}$ まて昇温速度 $20^{\circ} \mathrm{C} / \mathrm{min}$ で測定を行った。 


\section{7 吸水率の測定}

膜厚約 $50 \mu \mathrm{m}$, 幅 $20 \mathrm{~mm}$, 長さ $70 \mathrm{~mm}$ の試験片を $25^{\circ} \mathrm{C}$ の脱イオン水中に浸漬 した。浸漬前後の重量を測定し，下式よ り吸水率を算出した。

吸水率 $=($ 浸漬後の重量/浸漬前の 重量 -1$) \times 100$

\section{3. 結果と考察 \\ 3.1 二官能性環状カーボナート の合成}

前述した合成法により, Scheme 2 に 示す各種二官能性環状カーボナート 1a 〜 d を各々 $82,85,93$, および $67 \%$ の 収率で得ることが出来た。脂肪族系ある いは芳香族系のいずれであっても，また， それらがエーテル結合あるいはエステル結合のいずれを 有するあのであってむ, その構造に関わらず高い収率で 目的とする二官能性環状カーボナートが得られることが 確認された。このことから, 多種多様な構造および性質 を有するポリヒドロキシウレタンが合成できる可能性が 示された。

\section{2 ポリヒドロキシウレタンの合成}

Scheme 2 に示すように各種二官能性環状カーボナー 卜 $1 \mathrm{a} \sim \mathrm{d}$ と各種ジアミン $2 \mathrm{a} \sim \mathrm{d}$ とを重付加反応させる ことにより, 様々な構造のポリヒドロキシウレタン 3 を 得た。得られたポリマーの収率, 分子量, 分子量分布お よびフィルムの状態を Table 1 に示す。収率はいずれ あ $95 \%$ 以上で, 数平均分子量は 19,000 43,000 であっ た。これら分子量の差異はジアミンの種類により, アミ /基の求核性が異なり, 反応性に差が生じたためと考え られる。さらに, 立体障害や增粘による分子間の衝突頻 度の差も一因と考えられる。即ち, 了ミノ基の求核性と してはアルキル基を有する $2 \mathrm{a}, 2 \mathrm{c}$ および $2 \mathrm{~d}$ よりもフェ ニル基を有する $2 \mathrm{~b}$ の方か低く，さらに，立体的にも $2 \mathrm{~b}$ の方が高高いため，反応性は低くなると考えられる。実 際, Run 1〜3 が他よりも分子量が高いのはアルキル基 を有するジアミンを用いているためと考えられ, Run 4 と 5 およびRun 6 と 7 を比較しても同様の傾向にある。 ここで, Run 1 3における分子量の差異はジアミンの 分子量の差と, エーテル結合を有するモノマー間の親和 力の差が原因と考えられる。また，二官能性環状カーボ ナート 1c は比較的高分子量のポリエーテルであるため, 重合初期から粘度が高く，官能基濃度が低いため，見か けの分子量は上がるが，重合度は低いと考えられる。

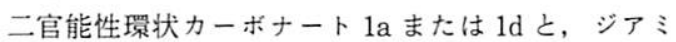

ン $2 \mathrm{a}$ または $2 \mathrm{~b}$ から得られたポリヒドロキシゥレタン の塗膜は, 原料二官能性環状カーボナートが剛直な構造 を有するためか，硬くて脆かった（Run 1，8，および 9)。一方, ジアミンとして比較的柔軟な構造の $2 \mathrm{c}$ また は $2 \mathrm{~d}$ を使用することにより，良好な状態のフィルムを 得ることができた（Run 2 および 3 ）。また，二官能性 環状カーボナートとして比較的柔軟な構造を有する $1 \mathrm{c}$ を使用した場合, 得られたフィルムは粘着性が大きく, 離型紙からの剥離が困難であった（Run 6 および 7$) 。$ さらに, 二官能性環状カーポナート $1 \mathrm{~b}$ を使用した場合, ジアミンとして $2 b$ を使用すると硬く脆いフィルムとな り，2a を使用すると常態放置した試料は良好であった が, 乾燥試料は硬く脆かった。このジアミンの種類によ るフィルム状態の差異は， R2 の自由度に起因すると考 えられ，R2 を变えることにより多種多様な性質のポリ ヒドロキシウレタンを設計できることが示唆される。

\section{3 ポリヒドロキシウレタンのフィルム物性}

Table 1でフィルム状態が良好であった Run 2〜 4の ポリヒドロキシゥレタンの抗張力および伸び率を測定し た。Table 2 に示すように, どの武料においても抗張力 に関しては常態放置した試料の方が乾橾試料よりも低く, 伸ひ率に関しては常態放置した試料の方が乾操試料より も高くなり，その值はフィルムの乾燥状態により大きく 変化することが分かった。このような変化は一般のポリ ウレタンでは钼察されず, 水酸基を有するポリヒドロキ シウレタン特有の現象である。これはポリヒドロキシウ レタンの親水性が高いため, 吸湿により水分をフィルム 内に取り込み，その水分が可塑剤として作用するために 引き起こされるものと推測される。即ち, 水により可塑 化された常態放置した試料は乾燥試料よりも流動性に富 
Table 2 Mechanical properties of polyhydroxyurethane films.

\begin{tabular}{ccccc}
\hline Run & \multicolumn{2}{c}{$\begin{array}{c}\text { Tensile strength } \\
\left(\mathrm{kgf} / \mathrm{cm}^{2}\right)\end{array}$} & \multicolumn{2}{c}{$\begin{array}{c}\text { Elongation } \\
\text { percentage (\%) }\end{array}$} \\
\cline { 2 - 5 } & Ambient $^{\text {a) }}$ & Dry $^{\text {a) }}$ & Ambient $^{\text {a) }}$ & Dry $^{\text {a) }}$ \\
\hline 2 & 180 & 324 & 285 & 196 \\
3 & 76 & 154 & 636 & 402 \\
4 & 310 & $-{ }^{-)}$ & 29 & $-{ }^{-)}$ \\
\hline
\end{tabular}

a) Dried under vacuum over silica gel and phosphorus pentoxide for 2 days and preserved under ambient atmospheric condition for 5 days.

b) Dried under vacuum over silica gel and phosphorus pento xide for 1 week.

d) Could not be measured.

み，抗張力の低下および伸び率の上昇を招いたものと考 えられる。

この結果を踏まえて, Run 2 および 3 のポリヒドロ キシゥレタンの吸水率を測定した。比較対照 1 には大日 本インキ化学工業 (搳製のクリスボン 8006HV（湿式加 工用ポリエステル系軟質標準タイプポリウレタン樹脂） を，比較対照 2 には同社製のクリスボン 9004 (乾式加 工用ポリエステル系超硬質タイプポリウレタン樹脂）を 使用した。Table 3 に示すように通常のポリウレタン （吸水率 1 2％）と比較してポリヒドロキシウレタンは, はるかに高い吸水率（30～35\%）を示すことが分かった。 このような従来には無い特性を持つ本研究のポリヒドロ キシウレタンは付加価值の高い新規な素材として期待で きる。

Table 3 Water absorption percentage of polyhydroxyurethanes and polyurethanes.

\begin{tabular}{cccc}
\hline Run & \multicolumn{2}{c}{ Water absorption } & percentage (\%) \\
\cline { 2 - 4 } & $24 \mathrm{~h}^{\text {a) }}$ & $48 \mathrm{~h}^{\text {a) }}$ & $72 \mathrm{~h}^{\text {a) }}$ \\
\hline 2 & 30 & 31 & 33 \\
3 & 34 & 34 & 35 \\
Ref. $1^{\text {b) }}$ & $<1$ & $<1$ & $<1$ \\
Ref. $2^{\text {c) }}$ & 2 & 2 & 2 \\
\hline
\end{tabular}

a) Dried under vacuum over silica gel and phosphorus pentoxide for 2 days and preserved under ambient atmospheric condition for 5 days.

b) Dried under vacuum over silica gel and phosphorus pento xide for 1 week.

d) Could not be measured.

更に, 本研究のポリヒドロキシウレタンは尿素結合, アロファネート結合, ピュレット結合といった耐熱性に 劣る構造を有さないため, 従来のポリウレタンと比較し
Table 4 Thermal Properties of polyhydroxyurethanes and polyurethanes.

\begin{tabular}{ccc}
\hline Run & $\begin{array}{c}\text { Thermal decomposition } \\
\text { temperature }\end{array}{ }^{\text {a) }}\left({ }^{\circ} \mathrm{C}\right)$ & $\begin{array}{c}\text { Weight loss at } 500^{\circ} \mathrm{C} \text { a) } \\
(\%)\end{array}$ \\
\hline 2 & 347 & 95 \\
3 & 348 & 92 \\
Ref. $1^{\text {b) }}$ & 315 & 87 \\
Ref. $^{\text {c) }}$ & 259 & 86 \\
\hline
\end{tabular}

a) Determined by TG-DTA under $\mathrm{N}_{2}$.

b) CRISVON $8006 \mathrm{HV}$ [soft standard type polyurethane (Dainippon Ink and Chemicals, Inc.)]

c) CRISVON 9004 [hard type polyurethane (Dainippon Ink and Chemicals, Inc.)]

て熱的に安定であると考えられる。そこで Table 1 run 2,3 の試料の TG-DTA を測定し，熱分解開始温度およ び $500^{\circ} \mathrm{C}$ における重量減少率を調べた。Table 4 に示す ように，熱分解開始温度はポリヒドロキシゥレタンの方 が $32 \sim 88^{\circ} \mathrm{C}$ 高く，熱的に安定であることが分かった。 $500^{\circ} \mathrm{C}$ における重量滅少率はポリウレタンの方が小さかっ だ。これはポリウレタン中の分岐構造と分子量効果によ るものと思われる。

\section{4. 結 言}

二官能性環状カーボナートの種類およびジアミンの種 類を変えることにより，各種の構造を有するポリヒドロ キシウレタンを合成することができた。これらのポリヒ ドロキシウレタンは分子中に水酸基を有しており，従来 のポリウレタンには見られない，30\%以上の高い吸水率 を示すことが分かった。これらのポリヒドロキシウレタ ンは尿素結合，アロファネート結合，またはビュレット 結合といった耐熱性に劣る構造を有さないため, 従来の ポリウレタンと比較して熱分解開始温度は $32 \sim 88^{\circ} \mathrm{C}$ 高 く，熱的に安定であることが分かった。このような物性 の向上および新規物性の発現から, 今後, ポリヒドロキ シウレタンの幅広い用途展開が期待される。

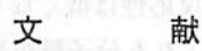

1) O. Bayer, Angew Chem., A59, 275 (1947).

2) P.Wright, A.P.C.Cumming, Solid Polyurethane Elastomers, Gordon and Breach Science Publishers, New York (1969).

3）ウレタン原料工業会発行，東京「ポリウレタン原料工業 の概要」, 1995 年

4) J. W. Rosthauser, K. Nchtkamp, Adv. Urethane Sci. Technology, 10, 121 (1987)

5) N. Kihara, N. Hara, T. Endo, J. Org. Chem., 58, 6198 (1993). 


\title{
$<$ Original $>$
}

\section{Synthesis of Polyhydroxyurethanes by Ring-opening Polyaddtion of $\mathrm{Bi}$-functional Cyclic Carbonates with Diamines and the Film Properties}

\author{
Hidetoshi TOMITA*, Hiroyuki HIDAKA ${ }^{* *}$, Fumio SANDA ${ }^{* *}$, and Takeshi ENDO** \\ * Japan Chemical Innovation Institute (JCII) \\ c/o Research Laboratory of Resources Utilization, Tokyo Institute of Technology \\ 4259 Nagatsuta-cho, Midori-ku, Yokohama, Kanagawa, 226-8503, Japan \\ ${ }^{*}$ Dainippon Ink and Chemicals, Inc. \\ 3-1 Takasago, Takaishi, Osaka, 592-0001, Japan \\ ** Research Laboratory of Resources Utilization, Tokyo Institute of Technology \\ 4259 Nagatsuta-cho, Midori-ku, Yokohama, Kanagawa, 226-8503, Japan \\ (Accepted for publication : March 1, 2000)
}

\begin{abstract}
Various kinds of polyhydroxyurethanes were synthesized by polyaddition of bis (cyclic carbonate) $\mathrm{s}$ and diamine to study the film properties. The tensile strength and elongation percentage of the polyhydroxyurethane films were varied with drying conditions probably due to absorbed water serving as a plasticizer. The water absorption percentages and thermal decomposition temperatures of the polyhydroxyurethane films were $>30 \%$ and $32 \sim 88^{\circ} \mathrm{C}$ higher than those of commercial polyurethanes, respectively.
\end{abstract}

(Received : February 4, 2000) 